\title{
The Impact of Parental Wealth on Early Living Standards in Israel $^{1}$
}

\author{
Seymour Spilerman \\ Columbia University
}

This article examines the role of parental wealth as a determinant of the living standards of young adults in Israel. Living standards were examined in terms of four measures: home ownership, car ownership, schooling after marriage, and a subjective evaluation by the respondent. Israel is a strategic site for examining the interplay between parental wealth and living standards because of the particular organization of its housing market. The study focuses on the role of parental wealth in the early years of marriage because young couples in Israel have great financial need at that time but are liquidity constrained. The main finding is that, net of indicators of parental SES and a couple's own income, parental wealth plays a substantial role in the living standards of young adults.

\section{INTRODUCTION}

There are two basic mechanisms by which parents transmit economic advantage to their children: via investments in human and cultural capital and through material assistance. Parental transfers in the form of socialization and schooling have been intensively studied under the rubric of the human capital/occupational attainment model (e.g., Becker 1975, Blau and Duncan 1967). Parental transfers of material resources-inter vivos gifts and bequests - have also been well documented, especially in recent years (e.g., McGarry and Schoeni 1997; Cox and Rank 1992; Holtz-

\footnotetext{
${ }^{1}$ This research was supported by the Ford Foundation grants 1000-1729, 1000-17291 and by a grant from the Brill-Scheuer Foundation. An earlier version was presented at the symposium Inclusion in Asset Building: Research and Policy, September 2000, sponsored by the Center for Social Development at Washington University, St. Louis. The author would like to thank Yuval Elmelech, Peter Bearman, and members of the Graduate Fellows Workshop at Columbia University for their helpful comments. Initial work on this study was carried out when the author was a Visiting Scholar at the Brookdale Institute, Jerusalem. Direct correspondence to Seymour Spilerman, Department of Sociology, Columbia University, 1180 Amsterdam Avenue, New York 10027. E-mail: ss50@columbia.edu

(C) 2004 by The University of Chicago. All rights reserved. 0002-9602/2004/11001-0001\$10.00
} 


\section{American Journal of Sociology}

Eakin and Smeeding 1994). Little attention, however, has been given to examining the consequences of the transfers for the well-being of offspring, though see Oliver and Shapiro (1995), Wolff (1996), and Conley (1999) for an important beginning. ${ }^{2}$ Even less consideration has been directed to assessing the respective contributions to living standards from the two transfer mechanisms, despite Becker's (1981) insights into the subject.

The theoretical framework that is most developed for explaining a family's living standard is an outgrowth of research into labor market attainment. Since the main determinant of attainment (measured by earnings or occupational status) that is amenable to exogenous manipulation is school achievement, much policy research has been focused on strategies for improving educational performance, motivated by a desire to reduce economic dependency and raise living standards, as well as to enhance economic productivity in the population.

For most U.S. families labor market attainment is, indeed, the principal determinant of economic well-being. Estimates of the proportion of household income deriving from labor market activity are in the neighborhood of $84 \%$ (Lenski 1984, p. 188; Slemrod 1991). Further reinforcing the inclination of social scientists to focus attention on labor market issues, the theoretical frameworks that have guided much stratification research (e.g., functional theory) have tended to emphasize the linkage between "services performed" and social rewards-a formulation more attuned to explaining inequality in society on the basis of labor market success than in terms of inherited wealth or financial assistance from parents and relatives (Davis and Moore 1945).

At the same time, there is a growing appreciation of the importance of household wealth as a determinant of living standards and economic wellbeing (e.g., Sherraden 1991, chap. 8; Spilerman 2000; Keister 2000). This assessment comes from a recognition that wealth has attractive features that make it a vital supplement to labor market rewards. In particular, the income that derives from wealth does not require a trade-off between leisure and work; also, unlike labor market earnings the income flow continues in time of illness and unemployment. Moreover, if the income generated from wealth holdings is taken in the form of capital gains, it is taxed more lightly than earnings- the maximum rate on capital gains is currently $15 \%$, versus $35 \%$ for labor market income. Last, in times of economic crisis the wealth principal can be consumed, which is hardly the case with "human capital."

\footnotetext{
${ }^{2}$ There is also an earlier literature that explored some of the consequences of household wealth for stratification issues; see especially Rumberger (1983) and Henretta and Campbell $(1978,1980)$. These articles anticipated the more recent studies but were limited by the paucity of household wealth data available to researchers at that time.
}

\section{PROOF 2}


Impact of Parental Wealth on Early Living Standards in Israel

Beyond the role played by household wealth in bolstering economic security, wealth holdings contribute to living standards in several ways. Household wealth can be held in a form that can be enjoyed (even as it appreciates), such as a fine painting or a vacation home. Wealth reduces the need to purchase life insurance, to save for retirement, or to offset a possible economic crisis in the future, allowing a larger share of household income to be directed to "lifestyle" expenditures. Even modest asset holdings, used as a source of collateral, can facilitate entry into the credit market, permitting a small business to be started or a home or car to be purchased on the basis of a down payment and a bank loan.

The growing recognition of the importance of asset holdings has stimulated new interest in the intergenerational transmission of wealth, along with the subsidiary theme of the impact of parental transfers on the living standards of offspring - witness the year 2000 election campaign debates on estate taxation. It is the accepted wisdom that a substantial proportion of current household wealth derives from parental transfers, though the precise figure is in dispute (Modigliani 1988; Kotlikoff and Summers 1981, 1988). In policy discourse it is also recognized that a large transfer of parental resources can give the recipient a leg up in the competition for an attractive living standard, and this matter of "initial conditions" raises issues of equity and fairness (Sen 1992). Yet, while much has been written about the lifestyles of the super rich who subsist on large inheritances (e.g., Mills 1956; Baltzell 1958), few studies have been carried out to reveal how modest levels of parental transfers might affect the living standards and attainments of offspring. ${ }^{3}$

From a theoretical point of view, an investigation into the impact of parental wealth and intergenerational transfers on the life chances of children raises critical issues in stratification research. While the importance of parental advantage has been well documented since the seminal work by Blau and Duncan (1967), the parental resources examined in these studies have largely been aspects of human capital—especially father's education and occupational attainment. The intergenerational transfer of material resources, by comparison, has been problematic in stratification theory, dating from the early functionalist formulations (e.g., Davis and Moore 1945); however, with the increase in asset holdings in the U.S. population and in that of other Western countries since World War II, its potential importance in the replication of inequality cannot be ignored.

The intent of the present article is to examine the impact of parental

${ }^{3}$ Some exceptions are the studies by Oliver and Shapiro (1995), Conley (1999), Kohli (1999), Semyonov and Lewin-Epstein (2001), and Wilhelm (1996). See Spilerman (2000) for a review of the literature on wealth and stratification processes.

PROOF 3 


\section{American Journal of Sociology}

wealth on the living standards of young couples in the State of Israel. Israel is a strategic site in which to investigate this matter because there is reason to expect that household wealth plays a more considerable role as a determinant of living standards in that country than in the United States (see below). To the extent this is the case, the task of discerning the ways by which parental wealth influences family well-being can be more easily accomplished with Israeli data. However, as we suggest in the concluding section, recent trends in the United States (the buildup of household wealth, the prospective elimination of estate taxation, income erosion among young families) are likely to make parental wealth increasingly relevant to the determination of living standards in the United States as well.

\section{HOUSEHOLD WEALTH IN ISRAEL}

There are several reasons why household wealth may have a greater impact on living standards in Israel than in the United States.

1. The cost of maintaining what is considered by Israelis to be a minimally acceptable living standard is high, relative to median earnings. Automobiles and household appliances, viewed by many as necessities, are subject to steep import duties that can raise an item's price substantially in excess of its cost in Europe or the United States. The median earnings in Israel, in contrast, is low. As a result, a considerable segment of the middle class-not just poor families-consumes its monthly earnings, restitution payments from Germany when available, and draws upon assistance from family members in order to cover its living expenditures (Plessner 1994, pp. 81-82). This existential situation was summarized some years ago in the headline of an Israeli newspaper reporting results from a consumer expenditure survey: "Income 2,800 Shekels, Expenditures 4,200 Shekels?" (Yideot Achronot 1991, p. 17). ${ }^{4}$

2. The wealth/income ratio in Israel is high. From a publication of the U.S. House of Representatives (1992, pp. 1446, 1573) a net worth/income ratio of 1.31 was calculated for the United States, based on median figures. Israel has not conducted a wealth survey, but using the median value of owner-occupied dwellings as a proxy for net worth, the corresponding ratio is 4.30 (calculated from a Central Bureau of Statistics survey [1994a, p. xiii; 1994b, p. 106]). While this computation pertains to home owners-

\footnotetext{
${ }^{4}$ Similar expressions of mystification about family economics in Israel have appeared in other sources. For example, in a New York Times article, Chartrand (1990, p. A4) remarked: "The average combined salary for a two-income family of four [in Israel] is . . . \$1,400 a month. . . . The same average family spends $\$ 1,650$ a month on basic expenses, leaving a gap of at least $\$ 250$.”
}

\section{PROOF 4}


Impact of Parental Wealth on Early Living Standards in Israel

$73 \%$ of the population-even assuming that nonowners have zero net worth the ratio would be 3.14 , still more than twice the U.S. figure. ${ }^{5}$

To summarize: living expenses are high in Israel and the median salary is low, but the majority of the population has considerable net worth, relative to income, though much of this is tied up in home equity.

There are two further considerations that pertain, especially, to young Israeli couples.

3. Israelis are home owners. Rental tenancy is not the norm and few apartments are available for long-term rental. Some $73 \%$ of householders own their residence, and much of the remaining tenancy is accounted for by new immigrants residing in temporary quarters and by collective institutional arrangements such as kibbutz dwellings (Central Bureau of Statistics 1994b, pp. xvi, 17).

What this means is that young Israeli couples must seek to purchase a residence early in their marital career. Yet, apartments are expensive, especially in the main cities. To ease the burden of acquisition the government offers subsidized mortgages to young couples (and to immigrants). But the subsidies are small, unless one is prepared to reside in an underdeveloped region of the country or, in recent years, in the disputed territories of the West Bank (Elmelech 1992). ${ }^{6}$ Because large down payments are usually required and bank loans difficult to secure, ${ }^{7}$ young couples—even young professional couples-face a liquidity constraint at the time of marriage. This makes parental assistance critical if the couple is to purchase housing, especially a residence in the more desirable, central region of the country.

4. Tax policy in Israel. Despite a high tax rate on labor market earnings-the top marginal rate was $50 \%$ in 1995 , the date of the survey examined in this study-capital gains has gone untaxed during most of

\footnotetext{
${ }^{5}$ An earlier estimate of the net worth/income ratio, for 1963/64, was 2.61 (Central Bureau of Statistics 1967, p. xxxix). This compares with a computed value of 1.27 for the United States in 1962 (Projector 1964, p. 291; U.S. Bureau of the Census 1964, p. 339).

${ }^{6}$ It is estimated that approximately $80 \%$ of settlers in the West Bank/Gaza reside there because of the low cost of housing rather than for ideological reasons (Federal News Service, "Hearing of the Near Eastern and South Asian Affairs Subcommittee of the Senate Foreign Relations Committee," October 15, 2003: http://www.lexisnexis.com; and Heller 2002).

${ }^{7} \mathrm{~A}$ recent account of housing mortgages in Israel noted: "Not so long ago a home buyer could consider himself lucky if he got a mortgage amounting to $25 \%$ of the value of the property; most would have gotten $15 \%$ or even $10 \%$. And even this paltry sum was conditional. The prospective mortgagor had to produce five guarantors . . . no easy feat under most normal circumstances" (de la Roca 2000).
} 
American Journal of Sociology

the country's history; ${ }^{8}$ also, there is no tax on intergenerational transfers, whether inter vivos gifts or bequests. Thus, wealth appreciation has been treated more favorably in tax law than earned income (despite the country's socialist origins), and asset transfers are unimpeded by considerations of taxation. This makes for a strong transmission of advantage across generations, which tends to reinforce a major fault line in Israeli society, between Ashkenazim (Israelis of European descent) and Mizrachim (Israelis of North African and Middle Eastern origin), analogous to the racial divide in the United States. In Israel, the former are more educated and have higher incomes and greater household wealth with which to assist their children. (For details on the role of ethnicity in Israeli life, see Kraus and Hodge [1990], Cohen and Haberfeld [1998], and Matras [1980].)

The preceding account makes clear the importance of intergenerational transfers in Israel and the life stage at which they are most consequential, namely at time of marriage. For this reason the present article examines the impact of parental wealth on several aspects of the living standards of young couples in the years immediately following marriage. Particular attention is given to the acquisition of a residence because this is a critical step in the establishment of a new family. Early home ownership, moreover, has been identified as an essential strategy in the accumulation of household wealth and as a consideration in the intergenerational transmission of advantage in both the United States and Europe (Mulder and Smits 1999; Engelhardt and Mayer 1994; Hamnett, Harmer, and Williams 1991).

The data for the study come from the 1994-95 Survey of Families in Israel, in which 1,607 respondents were interviewed on topics relating to work behavior, income, wealth, assistance received from parents, and views about financial obligations between parents and children. The data cover the urban, Jewish population of the country; Israeli Arabs were excluded because the basis of social obligation in that community is more rooted in tradition and local village arrangements, and a different study design would have been required to probe those intergenerational linkages.

Additionally, to be included in the survey, respondents had to be in their first marriage, with at least one spouse between the ages of 30 and 65 , and at least one spouse having resided in Israel during the prior 10 years. A comparison between characteristics of the sample and the civilian labor force in Israel (available from the author) reveals that except for

\footnotetext{
${ }^{8}$ Israel recently amended its tax law. Beginning in January 2003 capital gains have been taxed at a $15 \%$ rate.
}

\section{PROOF 6}


Impact of Parental Wealth on Early Living Standards in Israel

differences in the age distribution, which reflects the sample design, the correspondence is quite close.

\section{MOTIVATION AND ANALYTIC FORMULATION}

Marriage is a critical time in the lives of young Israelis. Most marry shortly after completion of military service, a four-year obligation for males during much of the period covered by survey questions about the early marital years. The accumulated resources of young couples therefore tend to be modest, yet the financial demands of launching a new household are considerable, especially the need to purchase and furnish a residence. Because these expenses often exceed a young couple's resources, newly marrieds tend to turn to their parents for assistance. In Israel it appears to be normative for parents to go to considerable lengths to provide financial support, possibly in recognition of the reality that in the absence of assistance their children's living standards would be severely compromised (Spilerman and Elmelech 2003).

Responses are reported in table 1 to three questions from the survey that tap parental attitudes toward the provision of financial aid to adult children. Question 1 is a scale item, assessing the perceived difficulty in Israel of coping without financial support from parents. Fully $90 \%$ of the sample believe that this is very difficult, if not impossible. Question 2 inquires about the duration of a parent's financial obligation. Some $57 \%$ of respondents believe that the obligation extends beyond a child's marriage year; indeed, until the time when assistance is no longer required. Question 3 measures the force of the parental obligation. Some $45 \%$ of respondents hold the view that it is a parent's responsibility to fund the bulk of a child's home purchase costs-even if this means working longer hours or accepting a second job.

The preceding is a rather strong expression of parental values and sets the stage for investigating the relationship between parental assets-a key ingredient in the ability to provide assistance — and the living standards of young couples. Parental transfers can be provided in diverse ways: loans, outright gifts, gifts contingent on the provision of services to parents, assistance with particular purchases and with ongoing household expenses. In the present article, however, we do not address the details of the transfer process but focus instead on the impact of parental resources (a measure of the capability to assist) on the outcome variables, aspects of the well-being of offspring. 


\section{American Journal of Sociology}

TABLE 1

Parental Values in Regard to the Provision of Financial Assistance to Adult Children

\begin{tabular}{|c|c|}
\hline Parental Values & Percentage \\
\hline \multicolumn{2}{|l|}{$\begin{array}{l}\text { 1. How important is it for parents in Israel to provide financial as- } \\
\text { sistance to their children? }(N=1,606)\end{array}$} \\
\hline a. Impossible to manage without parental assistance $\ldots \ldots \ldots \ldots \ldots$ & 24.5 \\
\hline b. Extremely difficult to manage without parental assistance $\ldots$... & 38.5 \\
\hline c. Very difficult without parental assistance $\ldots \ldots \ldots \ldots \ldots \ldots \ldots \ldots$ & 27.2 \\
\hline d. Not very difficult to manage without parental assistance ........ & 8.1 \\
\hline e. Easy to get by without parental assistance $\ldots \ldots \ldots \ldots \ldots \ldots \ldots$ & 1.7 \\
\hline 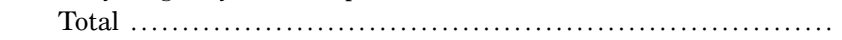 & 100.0 \\
\hline \multicolumn{2}{|l|}{$\begin{array}{l}\text { 2. Until when, in your opinion, should parents provide financial sup- } \\
\text { port to their adult children? }(N=1,606)\end{array}$} \\
\hline 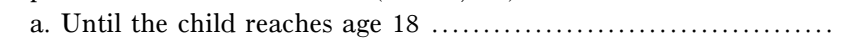 & 2.7 \\
\hline b. Until the completion of military duty . & 5.6 \\
\hline 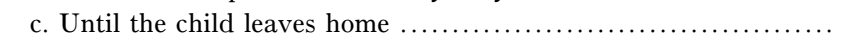 & 7.5 \\
\hline 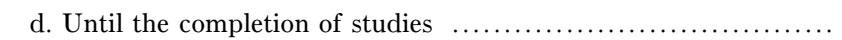 & 7.9 \\
\hline 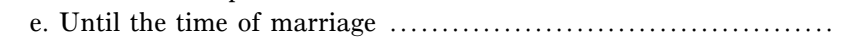 & 15.0 \\
\hline f. Until the adult child no longer requires financial support ........ & 56.7 \\
\hline g. Other, don't know & 4.6 \\
\hline 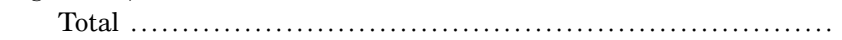 & 100.0 \\
\hline \multicolumn{2}{|l|}{$\begin{array}{l}\text { 3. In your opinion is it the responsibility of parents to carry the } \\
\text { main financial burden for the purchase of an apartment at the } \\
\text { time of a child's marriage? }(N=1,595)\end{array}$} \\
\hline $\begin{array}{l}\text { a. Yes, even if this means that the parents have to work longer } \\
\text { hours or accept a second job } \ldots \ldots \ldots \ldots \ldots \ldots \ldots \ldots \ldots \ldots \ldots \ldots \ldots \ldots \ldots \ldots \ldots\end{array}$ & 45.1 \\
\hline b. Yes, but only if the parents have the financial means ............. & 51.0 \\
\hline $\begin{array}{l}\text { c. No, it is the responsibility of the children to carry this financial } \\
\text { burden }\end{array}$ & 3.9 \\
\hline 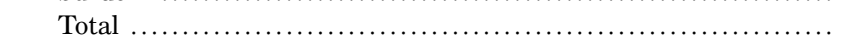 & 100.0 \\
\hline
\end{tabular}

\section{Dependent Variables}

The living-standard variables cover some of the main dimensions of family welfare: home and automobile ownership, formal education by either member of the couple, as well as a subjective measure of well-being. All questions were asked in reference to the first three years of marriage. ${ }^{9}$ Home and automobile ownership are dichotomous variables; formal education is coded "0"-"2", a count of the number of spouses who attended school during all or part of the three-year period. The subjective livingstandard variable is coded " 1 "-" 5 ," with " 1 " equal to much below the

\footnotetext{
${ }^{9}$ A three-year interval was chosen because some decisions at marriage can require a lengthy waiting period before realization. For example, even after a decision has been made to purchase a home, a suitable residence must be found, or constructed, and a bank mortgage arranged.
}

\section{PROOF 8}


Impact of Parental Wealth on Early Living Standards in Israel

average in Israel, and " 5 " equal to much above the average. The distribution of responses on the four dependent variables is reported in appendix table A1. Excluded from the tabulation are 76 couples who were married for less than three years at the time of the survey; the dependent variables are considered to not be defined for these households.

Table 2 presents bivariate associations between the living standard measures and a proxy for parental wealth-number of parental homes. ${ }^{10}$ In the case of each measure there is considerable sensitivity to the parental asset variable. Yet, while the effects are strong, to build an explanatory model it is necessary to control for other parental terms that are correlated with the wealth proxy and could influence living standards. In particular, there is a considerable literature that relates parental human capital to children's earnings (e.g., Jencks et al. 1972; Duncan, Featherman, and Duncan 1972). Also, we want to ascertain the path of influence of parental wealth: whether it is through the encouragement of educational attainment and income of children or via direct monetary transfers. To accomplish this we utilize a multivariate formulation.

\section{Explanatory Variables}

The regressors of primary interest are of two sorts: variables that tap the couple's ability to finance a particular purchase from their own income and savings and measures of a parent's ability to assist with the expense of an item. Regarding the couple's own resources, we lack income data for respondents in their early years of marriage. Moreover, were such data available they would be of questionable utility, considering the range in year of marriage in our sample-from 1949 to 1994 - and the great variation in the inflation rate in Israel during this period, from single digit to values that exceeded $200 \%$ annually in the early 1980s. Instead, we proxy household income in the early years of marriage by three variables: husband's education, number of spouses employed, and age of husband at marriage. The last is intended to tap both the income returns to labor market experience and the accumulated savings of the principal wage earner.

The education variable requires special treatment. The measure of husband's education available to us ("EducH") is years of schooling in 1995, the survey year. Some $23 \%$ of husbands in the sample continued their studies after marriage, either full-time or part-time; for them, the reported schooling level probably overstates educational attainment at the time of marriage. Rather than delete these observations, we correct for the mis-

${ }^{10}$ The reason for selection of this proxy is explained below. The calculation of parental homes is for husband and wife when each was age 16.

PROOF 9 
American Journal of Sociology

TABLE 2

Bivariate Associations between the Living Standard Measures and Number of Parental Homes

\begin{tabular}{|c|c|c|c|}
\hline \multirow{2}{*}{$\begin{array}{l}\text { Living StandaRd MEasure } \\
\text { (Years } 1-3 \text { of Marriage)* }\end{array}$} & \multicolumn{3}{|c|}{ Number of Parental Homes ${ }^{\dagger}$} \\
\hline & 0 & 1 & 2 \\
\hline Home ownership (\%) ........... & 41.7 & 56.5 & 68.4 \\
\hline Auto ownership (\%) .......... & 16.8 & 36.5 & 51.9 \\
\hline $\begin{array}{l}\text { Number of spouses who stud- } \\
\text { ied after marriage (mean) ... }\end{array}$ & .28 & .38 & .58 \\
\hline $\begin{array}{l}\text { Subjective standard of living } \\
\quad(\text { mean }) \ldots \ldots \ldots \ldots \ldots \ldots \ldots\end{array}$ & 2.67 & 2.85 & 2.91 \\
\hline$N$ & 192 & 369 & 649 \\
\hline
\end{tabular}

* Questions were worded in terms of "ever owned" or "ever studied" in this time period.

${ }^{\dagger}$ Number of homes owned by parents when husband and wife were each age 16 .

measurement by introducing an indicator variable-EducH $(i)$ - coded "1" if the husband continued studies after marriage and " 0 " if he did not. With this coding, $b_{1}$ in the regression

$$
\text { Depvar }=b_{1} \mathrm{EducH}+b_{2} \operatorname{EducH}(i)+\text { other terms }+e
$$

reports the effect of husband's education at time of marriage on a dependent variable, while $b_{2}$ conveys the average additional effect from mismeasurement of the education term. A negative $b_{2}$ is expected and would suggest that, where the husband continued his studies, the couple's reported living standard in the early years of marriage was below the value predicted by the education term.

The measurement of parental wealth at time of marriage also poses problems, not the least being the wide range in year of marriage and the fluctuation in real asset values because of the changing rate of inflation. But an even greater difficulty is posed by the immigrant background of Israelis; many came from countries in Europe. Africa, and the Near East, each with its own currency. With this complexity, it was decided that the most reliable measure of parental wealth would be one based on asset ownership, especially home ownership. The constructed proxy is "number of homes owned by parents of husband and wife when each was 16." Cases where husband or wife did not live with a parent at this age-not uncommon for immigrants who spent the World War II years in Europewere noted by an indicator term.

Other variables included in the study that may affect the receipt of parental assistance are number of siblings of husband and wife, number of living parents at the time of marriage, and husband's and wife's fathers' occupational status (SES). The rationale for the first is that it measures competing demands for the parental resources, while the parental status

\section{PROOF 10}


Impact of Parental Wealth on Early Living Standards in Israel

terms (measured by Vered scores-Kraus [1976]) serve as a proxy for parental incomes and are introduced to obtain parental wealth effects that are net of other sources of parental assistance.

Two additional sets of regressors warrant mention. Dummy terms were added for year of marriage and for geographic region of origin: Israel, Western Europe/United States, Eastern Europe, Africa (mainly Egypt, Algeria, Morocco), and Asia (principally Iraq, Iran, Yemen). The former were included because marital year correlates with the level of economic development in Israel and may therefore tap the ability of parents in different decades to make transfers. The latter terms permit a consideration of the extent to which disparities among the ethnic groups in providing assistance to children can be attributed to differences in parental resources. ${ }^{11}$ For convenience, we base the couple's ethnic affiliation on husband's origin. Also, to better reflect cultural background, Israel-born husbands were coded in terms of father's country of birth. Thus, the "Israel" ethnic category refers to couples in which both husband and husband's father were born in Palestine/Israel.

A final issue concerns the treatment of missing data. The amount of missing data is not excessive for a survey that inquired about parental characteristics at a time that, for some respondents, refers to the World War II period (see appendix table A1 for details). Deletion of cases with missing data is not recommended because of the loss of statistical power and because, unless the missingness is completely at random (MCAR), listwise deletion can generate biased parameter estimates (King et al. 2001). Instead, multiple imputation was employed with Schafer's NORM algorithm (Schafer and Olsen 1998). ${ }^{12}$ Formally, NORM requires the variables to be multivariate normal; in practice, this imputation method appears to also work well with categorical and dichotomous variables (King et al. 2001; Schafer and Olsen 1998, p. 5).

Each imputed data set was constructed by filling in the missing data with a regression prediction from other variables in the data set, to which a random component had been added (DA algorithm)—See Allison (2002) for details. Five data sets were created in this way using the NORM program. The regression models were run with each data set and the final coefficient estimates and standard errors calculated by pooling the esti-

\footnotetext{
${ }^{11}$ See Semyonov, Lewin-Epstein, and Spilerman (1996) for an account of ethnic differences in living standards in Israel.

${ }^{12}$ It is well known that single imputation procedures for missing data, even with a random component added, produce biased standard errors, generally inflating the value of significance tests (Allison 2002, p. 29).
}

PROOF 11 


\section{American Journal of Sociology}

mates using the formulas in Schafer and Olsen (1998). These are the regression results reported in this article. ${ }^{13}$

The term for number of parental homes was treated differently. This variable had been coded as missing in instances where a question about home ownership was not applicable: e.g., the respondent grew up in an internment camp after World War II or in a collective settlement in Israel. Rather than impute ownership/rental status to these cases, an indicator term was created. The indicator term was coded "1" for cases that lacked data on parental home ownership and "0" otherwise. Analogous to the discussion of equation (1), the coefficient of the indicator term conveys the average effect of the cases that were missing parental ownership information, controlling for the other variables.

Regression results for the four living-standard measures are reported in tables 3 and 4. Each measure was first regressed against the ethnic terms and year of marriage (the "zero-order relationships"), then against the full set of explanatory variables. ${ }^{14}$ Note that table 3 and column 1 of table 4 report logistic models because the dependent variables are dichotomous, while the schooling regression (column 2 of table 4) is logistic because the dependent variable is the proportion of members of a couple engaged in study, based on a binomial outcome $(0,1$, or 2 members in school). ${ }^{15}$ The above regressions were estimated within the generalized linear models (GLM) framework,

$$
g[E(y)]=b_{0}+b_{1} x_{1}+b_{2} x_{2}+\cdots+b_{n} x_{n}
$$

where the link function $g[$ ] is logit, and the distribution family is specified as binomial $(n=1)$ for the initial two dependent variables and as binomial $(n=2)$ for the schooling equation. The subjective living standard regression (column 3 of table 4) was estimated with an ordered logit model because of the ranked categorical structure of that dependent variable.

\footnotetext{
${ }^{13}$ A comparison with the coefficient estimates using indicator terms for variables with missing data showed little difference in results; in no case would a substantive conclusion be altered.

${ }^{14}$ Only the full models are reported for the three dependent variables in table 4 .

${ }^{15}$ Use of a binomial formulation presumes that schooling decisions by husband and wife are made independently, an assumption likely to be violated in practice. A simultaneous probit model was considered, which would permit the determinants of husband's and wife's education to be modeled separately, but was abandoned because of a lack of covariates necessary to identify the two equations. Ordered logit regression, an alternative model specification, yielded similar results to the binomial formulation.
}

\section{PROOF 12}


Impact of Parental Wealth on Early Living Standards in Israel

TABLE 3

Determinants of Home Ownership in First Three Years of Marriage, Logistic REgRESSIONS, UNSTANDARDIZED COEFFICIENTS

\begin{tabular}{|c|c|c|c|c|}
\hline \multirow{2}{*}{$\begin{array}{c}\text { Variable } \\
\text { Constant } \ldots \ldots \ldots \ldots \ldots \ldots \ldots \ldots \ldots \ldots\end{array}$} & \multicolumn{2}{|c|}{ (1) } & \multicolumn{2}{|l|}{$(2)$} \\
\hline & -.371 & $(.267)$ & $-2.086 * *$ & $(.751)$ \\
\hline \multicolumn{5}{|l|}{ Origin region: ${ }^{\mathrm{a}}$} \\
\hline Western Europe .................. & .387 & $(.271)$ & .269 & $(.283)$ \\
\hline Eastern Europe $\ldots \ldots \ldots \ldots \ldots \ldots \ldots$ & .189 & $(.239)$ & .019 & $(.249)$ \\
\hline 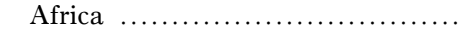 & $-.566 *$ & $(.242)$ & -.231 & $(.258)$ \\
\hline Asia $\ldots \ldots \ldots \ldots \ldots \ldots$ & -.086 & $(.242)$ & .110 & $(.255)$ \\
\hline \multicolumn{5}{|l|}{ Year of marriage (YOM) ${ }^{\mathrm{b}}$} \\
\hline 1960-69 …............ & $.801 * *$ & $(.190)$ & $.670 * *$ & $(.200)$ \\
\hline 1970-78 & $1.100 * *$ & $(.184)$ & $.972 * *$ & $(.197)$ \\
\hline$\ldots \ldots \ldots \ldots \ldots \ldots \ldots \ldots \ldots$ & $.868^{* *}$ & $(.192)$ & $.590 * *$ & $(.209)$ \\
\hline 1984-94 „................. & $1.077^{* *}$ & $(.202)$ & $.603 * *$ & $(.232)$ \\
\hline \multicolumn{5}{|l|}{ Human capital/employment: } \\
\hline Education—husband ...... & & & .023 & $(.020)$ \\
\hline Education—husband $(i)^{c} \ldots \ldots \ldots \ldots$ & & & -.093 & $(.146)$ \\
\hline No. spouses employed in YOM .... & & & $.350 * *$ & $(.096)$ \\
\hline Age of husband in YOM & & & $.047 * *$ & $(.017)$ \\
\hline \multicolumn{5}{|l|}{ Parental socioeconomic status: } \\
\hline SES husband's father $\left(\times 10^{-2}\right) \ldots \ldots$ & & & -.489 & $(.333)$ \\
\hline SES wife's father $\left(\times 10^{-2}\right) \ldots \ldots \ldots$ & & & -.014 & $(.323)$ \\
\hline \multicolumn{5}{|l|}{ Parental resource terms: } \\
\hline No. parents alive in YOM & & & .108 & $(.181)$ \\
\hline No. parental homes $\ldots \ldots \ldots \ldots \ldots . . .$. & & & $.444 * *$ & $(.087)$ \\
\hline No. parental homes $(i)^{\mathrm{d}}$. & & & $.625 * *$ & $(.178)$ \\
\hline No. brothers/sisters $(\log ) \quad \ldots \ldots \ldots \ldots$ & & & $-.380 * *$ & $(.121)$ \\
\hline 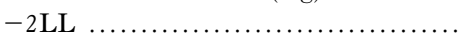 & 1,986 & & 1,912 & \\
\hline 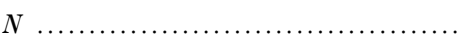 & 1,531 & & 1,531 & \\
\hline
\end{tabular}

NotE. - Estimates from multiple imputation, five data sets (see text for details). SEs in parentheses.

${ }^{a}$ Omitted term is for Israel origin.

${ }^{\mathrm{b}}$ Omitted term is for marriage before 1960.

${ }^{\mathrm{c}}$ Indicator term for whether husband was a student during first three years of marriage.

${ }^{\mathrm{d}}$ Indicator term for missing data on parental homes. See text for details.

$* P<.05$, two-tailed test.

** $P<.01$.

\section{THE IMPACT OF PARENTAL WEALTH}

\section{Home Ownership at Marriage}

First consider the full model in table 3 and ignore the ethnic terms. Column 2 reports the determinants of home ownership by a young couple in the early years of marriage. The first four substantive regressors following the time period terms are measures of the young couple's own resources, which could cover at least part of the cost of financing an apartment purchase. From among these variables the term for husband's education - a measure of human capital—is not statistically significant. 


\section{American Journal of Sociology}

TABLE 4

Determinants of Automobile Ownership, Schooling, and Subjective Standard of Living in First Three Years of Marriage, Unstandardized Regression COEFFicients

\begin{tabular}{|c|c|c|c|c|c|c|}
\hline \multirow{3}{*}{$\begin{array}{c}\text { Variable } \\
\text { Constant } \ldots \ldots \ldots \ldots \ldots \ldots \ldots \ldots \ldots\end{array}$} & \multicolumn{2}{|c|}{$\begin{array}{l}\text { Automobile } \\
\text { Ownership } \\
\quad(1)\end{array}$} & \multicolumn{2}{|c|}{$\begin{array}{l}\text { Schooling }{ }^{\mathrm{b}} \\
\text { (2) }\end{array}$} & \multicolumn{2}{|c|}{$\begin{array}{l}\text { Subjective } \\
\text { Standard of } \\
\text { Living }^{\mathrm{c}} \\
\text { (3) }\end{array}$} \\
\hline & $-7.185 * *$ & $(.884)$ & $-1.495 *$ & $(.582)$ & & \\
\hline & & & & & & \\
\hline Western Europe & .114 & $(.304)$ & .041 & $(.207)$ & .512 & $(.266)$ \\
\hline Eastern Europe & .020 & $(.273)$ & -.010 & $(.188)$ & $.508^{*}$ & $(.237)$ \\
\hline Africa $\ldots \ldots \ldots \ldots$ & -.271 & $(.282)$ & -.261 & $(.208)$ & 283 & $(.246)$ \\
\hline Asia $\ldots \ldots \ldots \ldots \ldots \ldots \ldots$ & -.032 & $(.277)$ & $-.556 * *$ & $(.206)$ & 179 & $(.243)$ \\
\hline Year of marriage $(\mathrm{YOM}) \mathrm{e}^{\mathrm{e}}$ & & & & & & \\
\hline 1960-69 …........... & $1.047 * *$ & $(.333)$ & $.591 * *$ & $(.205)$ & $.424 *$ & $(.192)$ \\
\hline 1970-78 & $2.082 * *$ & $(.321)$ & $.997 * *$ & (.199) & $.466 *$ & $(.186)$ \\
\hline 1979-86 & $2.613 * *$ & $(.330)$ & $1.091 * *$ & (.206) & .357 & (.198) \\
\hline 1984-94 ...... & $3.112 * *$ & $(.347)$ & $1.296 * *$ & $(.220)$ & $.705 * *$ & $(.221)$ \\
\hline Human capital/employment: & & & & & & \\
\hline Education-husband & $.077 * *$ & $(.025)$ & & & $.042 *$ & (.019) \\
\hline Education-husband $(i)^{\mathrm{f}}$ & -.085 & $(.155)$ & & & -.200 & $(.139)$ \\
\hline No. spouses employed in & & & & & & \\
\hline YOM $\ldots \ldots \ldots \ldots \ldots$ & $.404 * *$ & $(.106)$ & & & $.327 * *$ & $(.092)$ \\
\hline Age of husband in YOM ....... & $.056^{* *}$ & $(.016)$ & $-.054 * *$ & $(.012)$ & $.039 * *$ & $(.013)$ \\
\hline $\begin{array}{l}\text { Parental socioeconomic status/ed- } \\
\text { ucation: }{ }^{\mathrm{g}} \ldots \ldots \ldots \ldots \ldots \ldots \ldots \ldots \ldots \\
\text { SES-husband's father }\end{array}$ & & & & & & \\
\hline$\left(\times 10^{-2}\right) \ldots \ldots \ldots \ldots \ldots$ & .277 & $(.372)$ & $.007 *$ & $(.003)$ & 111 & $(.331)$ \\
\hline SES-wife's father $\left(\times 10^{-2}\right) \ldots$ & $1.232 * *$ & $(.360)$ & -.003 & $(.003)$ & $.699^{*}$ & $(.317)$ \\
\hline $\begin{array}{l}\text { Education-husband's } \\
\quad \text { father } \ldots \ldots \ldots \ldots \ldots \ldots \ldots \ldots\end{array}$ & & & $.028 *$ & $(.014)$ & & \\
\hline Education—wife's father ....... & & & $.069 * *$ & $(.014)$ & & \\
\hline Parental resource terms: & & & & & & \\
\hline No. parents alive in YOM . & $.548^{*}$ & $(.243)$ & .083 & $(.181)$ & -.018 & (.169) \\
\hline No. parental homes $\ldots \ldots \ldots$ & $.441^{* *}$ & $(.102)$ & $.266 * *$ & $(.079)$ & $.213 * *$ & $(.084)$ \\
\hline No. parental homes $(i)^{\mathrm{h}}$. & $.664 * *$ & $(.216)$ & .216 & $(.172)$ & .061 & $(.174)$ \\
\hline No. brothers/sisters $(\log ) \ldots \ldots \ldots$ & $-.283 *$ & $(.135)$ & $-.389 * *$ & $(.102)$ & .062 & $(.115)$ \\
\hline 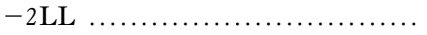 & 1,609 & & 2,888 & & 3,142 & \\
\hline$N \ldots \ldots$ & 1,531 & & 1,531 & & 1,531 & \\
\hline
\end{tabular}

Note.-Estimates from multiple imputation, five data sets (see text for details). SEs in parentheses.

${ }^{a}$ Logistic regression.

${ }^{\mathrm{b}}$ Logistic regression. Dependent variable is the proportion going to school from among the two members of the couple, formulated as a binomial model. See text for details.

c Ordered logit model. Cut points for the ordinal variable omitted from table.

${ }^{\mathrm{d}}$ Omitted term is for Israel origin.

e Omitted term is for marriage before 1960

${ }^{\mathrm{f}}$ Indicator term for whether husband was a student during first three years of marriage.

${ }^{g}$ Socioeconomic status (SES) coded according to Vered scores for Israeli occupations (Kraus 1976).

${ }^{\mathrm{h}}$ Indicator term for missing data on parental homes. See text for details.

* $P<.05$, two-tailed test.

** $P<.01$.

\section{PROOF 14}


Impact of Parental Wealth on Early Living Standards in Israel

This variable was introduced as a proxy for husband's earnings capacity at time of marriage, but it is probably a better indicator of earnings potential in later life. As Ornstein (1976, p. 143) has noted, the labor market income and occupational status of young workers are not well differentiated by educational attainment. The indicator for husband's schooling during the first three years of marriage-a correction term to pick up the effect from a possible mismeasurement of education-is also insignificant, though it has the expected negative sign.

The remaining labor force variables-number of spouses employed in the early years of marriage and age of husband-are better measures of the income flow into a young household, and both are significant. Twoearnings families and couples with older husbands have more resources for a home purchase in the period following marriage. The coefficients reported in the table are logits, but the odds ratios, obtained by exponentiating the coefficients, provide a more easily interpretable metric. These show that an additional employed spouse increases the odds of a home purchase in the initial years of marriage by some $42 \%$. Similarly, each additional year in husband's age raises the odds by $5 \%$, reflecting the likelihood that the husband has advanced in his career and has higher income, as well as the financial savings that would accrue with age.

However, it is the parental resource variables that are the focus of our interest. They are measured by number of parental homes when husband and wife were each 16 and by number of siblings of husband and wife. Not surprisingly, in light of the introductory comments about the importance in Israel of parental assistance in the home acquisition process, the number of parental homes is highly significant and has a strong impact on the odds of home ownership in the early years of marriage. Exponentiating the logistic coefficient indicates that an increase of one parental home raises the odds of ownership by 56\%; an increase from zero to two parental homes raises the odds by $143 \%$. Thus, the consequence of parental wealth for the capability of a young couple to purchase a residence early in their marital career is considerable. Note, incidentally, that this effect is net of the fathers' occupational terms, which are not significant.

The indicator term for missing data on parental home ownership is also significant, with an odds ratio of 1.87 . This says that where the respondent or spouse did not live with parents at age 16, or where the respondent declined to provide parental asset information, the odds of home ownership at marriage are $87 \%$ greater than for couples where neither set of parents was a home owner. Essentially, the missing data population with respect to parental home ownership acts like couples with an average of 1.41 parental homes $\left(e^{[1.41][.4448]}=1.87\right)$.

This result is not surprising. The baseline group-couples with no parental homes-represents the poorest segment of the Israeli population in

PROOF 15 


\section{American Journal of Sociology}

terms of parental assets. The missing data category, by comparison, contains couples with substantial family resources who declined to respond to the parental asset question, as well as couples where one set of parents owned a home but his/her spouse did not live with parents at age 16 or grew up in an institutional setting such as a displacement camp or a kibbutz.

The second parental term-number of siblings of husband and wifewas introduced as a measure of the demands on parental assets. Where there are several siblings it is expected that the wider scope of parental obligations will reduce the level of assistance provided to each child. This expectation is borne out. The sibling term is significant and negative; with four sibs-close to the median for husband plus wife in the Israeli population - an additional brother or sister reduces the odds of ownership by $8.2 \%{ }^{16}$ The final parental variable, number of living parents at time of marriage, was not significant. ${ }^{17}$

To summarize: while the employment activity and accumulated savings of a young couple make a discernible contribution to the likelihood of home ownership in the early years of marriage, the effect of parental wealth-even when imperfectly measured by number of parental homes several years before the marriage-is massive. Young couples from families that have the resources to provide financial assistance are greatly advantaged in their quest for early home acquisition. In the Israeli context, in which there is little long-term rental housing, the estimates from equation (2) translate into a predicted home ownership probability of .49 and .70 for young couples having zero and two parental homes, respectively, but who are otherwise identical on the measured characteristics in the regression. In short, parental wealth, as proxied by number of parental homes, creates the possibility of an early transition to a stable residence arrangement.

\section{Automobile, Education, Subjective Living Standard}

In Israel, an automobile is a luxury item since public transportation is quite dependable in most sections of the country. Moreover, car prices are high, as a result of steep import duties, and gasoline is expensive-as it

${ }^{16}$ Since number of sibs is a logged term in the model, the multiplier effect is a function of this number and was calculated as

$$
\exp ^{b \ln (N+1)} / \exp ^{b \ln (N)}=[(N+1) / N]^{b},
$$

where $N=4$ and the value of $b$ was taken from table 3 .

${ }^{17}$ There were only 12 cases in which neither husband nor wife had a living parent at the time of marriage. Consequently, this variable essentially serves as a contrast between one or both members of the couple having a living parent.

\section{PROOF 16}


Impact of Parental Wealth on Early Living Standards in Israel

is in much of Western Europe. Nonetheless, automobile ownership is greatly valued by Israelis. It is also clear from appendix table A1 that some $40 \%$ of young couples in our samples found the means to purchase a car within their first three years of marriage.

In Column 1 of table 4 the determinants of automobile ownership are examined. The parental effects are similar in pattern to those in the home ownership regression: the odds of acquisition increase with parental wealth and decline with number of siblings of husband and wife. What is noteworthy in this equation is the greater importance of the labor market terms, relative to the parental resource variables, as a factor in automobile acquisition. Husband's educational attainment is now significant, and the other proxies for a couple's earnings have marginally greater effects than in the home ownership equation. The parental resource terms, by comparison, show no consistent difference in the two equations - though number of living parents now attains significance. We would like to interpret the findings as suggesting that the financing of an automobile, since it is a luxury item, comes more from the couple's own resources than from parental assets, but the results provide only weak evidence for this contention; the parental resource effects remain considerable even in the case of this nonessential item.

Whether or not formal education was continued by husband or wife in the years immediately following marriage is examined in column 2 of table 4. Since zero, one, or two spouses might have attended school, the dependent variable is specified as binomial $(n=2)$ and estimated in GLM with a logistic link function. With this formulation, the model describes the proportion of the couple's members attending school, expressed in the $\log$ odds metric.

The present analysis also requires a different specification of the explanatory variables from the preceding models. First, husband's educational attainment in 1995 was dropped from the regressors because it can hardly serve as a determinant of the dependent variable. Second, the measure of work activity by husband and wife following marriage was deleted because this represents an alternative use of time to schooling, rather than standing as a determinant of formal study. Third, in conformity with the stratification literature, terms for the educational attainment of husband's and wife's fathers were added; these proxy the extent to which educational attainment was encouraged in a parental household and are well established as causal links in the achievement of offspring (e.g., Blau and Duncan 1967). With this revised formulation we address the impact of parental wealth on the decision to continue schooling, net of the contribution of parental values.

Observe, first, that parents' education and occupational status have the effects expected of them. The educational attainments of both husband's

PROOF 17 
American Journal of Sociology

and wife's fathers are statistically significant. The same is true for husband's father's SES, though the comparable term for wife's father is not significant. With the exception of the last, these results replicate established findings (e.g., Jencks et al. 1972; Featherman and Stevens 1982). Age of husband at marriage is also significant and negative; not surprisingly, a late marriage reduces the odds of attending school because desired schooling is likely to have already been completed. Turning to the parental resource proxies_number of parental homes and sibship size-both are significant with the expected signs: number of parental homes increases the likelihood of study; sibship size depresses the prospects of additional schooling.

A comparison of the relative importance of socialization and home environment versus parental wealth is informative. If the educational attainments of husbands' and wife's fathers were each raised by four years (treated here as independent effects) - e.g., from high school completion to college graduation-this would translate into a $48 \%$ increase in the odds of study by the young couple. A change from zero to two parental homes, by comparison, has a somewhat greater impact: an improvement of $70 \%$ in the odds. The conclusion, then, is that home environment and parental resources both play a considerable role in the decision to continue with schooling-the latter effect, however, has not been adequately recognized in the stratification literature.

Respondents were also asked to rate their standard of living during the first three years of marriage, relative to the average living standard in Israel; this subjective measure ranges from " 1 ," very low, to " 5 ," very high. A subjective measure is a very different sort of beast from the three objective items we have thus far examined. It requires a judgment by the respondent about the average living standard in the country, as well as an assessment of his/her own quality of life. Moreover, the latter is vulnerable to individual dispositions to see oneself as middle-class and successful or, possibly, as disadvantaged and deprived.

With these caveats, we report in column 3 of table 4 a model of the determinants of the subjective living standard. Because of the ranked categorical structure of this dependent variable, ordered logit regression was employed. The results are largely consistent with the earlier findings. Husband's education and the other proxies for household income in the early years of marriage are significant and positive, as is the parental wealth measure, number of parental homes. Number of siblings, does not, however, have a significant effect.

To summarize the preceding material: In all of the regressions the proxy for parental wealth was statistically significant, often having a substantial effect on the dependent variable. Number of siblings-introduced to obtain a refined assessment of the parental resources available for transfer

\section{PROOF 18}


Impact of Parental Wealth on Early Living Standards in Israel

in that it measures competing demands for the resources-has the expected (negative) sign and is significant in three of the four regressions; indeed, in all the equations with objective measures. Thus, in combination, the four models make clear that parental wealth plays a considerable role in the living standards of young couples in Israel, enhancing their likelihood of car ownership, engaging in study, and, most importantly, acquiring a residence. Moreover, these effects are net of parental occupational status and the proxies for household income of the couple.

A comment on the time period dummies. In the home ownership and subjective living standard equations there is no discernible pattern, whereas in the equations for automobile ownership and schooling there is a clear trend to higher rates of acquisition over time. These findings can be understood from the point of view that home ownership has been a necessity throughout the country's history, whereas an automobile is a luxury item, more frequently acquired in recent years as median family income in Israel has increased. Education shows the same trend as automobile ownership, but the time path is less steep, especially after the initial period. Possibly schooling was once viewed as a luxury item, when household incomes were low. But it is also the case that the number of colleges and universities in Israel has expanded over time, in excess of the rate of population growth, permitting a larger proportion of young adults to contemplate advanced study and enroll in institutions of higher education.

\section{Ethnic Effects}

The ethnic dimension constitutes a major fault line in Israeli society. Ethnicity, defined in terms of continent and, sometimes, country of origin, has been a basis for political mobilization in the country and is associated with distinct differences in educational attainment, household income, and living standards (Cohen and Haberfeld 1998; Shavit 1984; Smooha and Kraus 1985). A discussion of the ethnic effects was deferred until the full model of the determination of early living standards could be explored. We now turn to an examination of the ethnic disparities. The question of interest concerns the extent to which they can be attributed to differences in parental financial resources, net of the human capital endowments and the employment status of young couples.

For simplicity, we consider the ethnic gap to equal the largest difference between the ethnic terms in an equation. Regarding home ownership, from column 1 of table 3 we compute the gap to equal .953 (in the logit metric) - the difference between Western European and African origin Israelis. Introduction of controls for the human capital/employment experiences of husband and wife and for the parental SES terms (not shown) 
American Journal of Sociology

lowers the gap to 890 - a reduction of $7 \%$ from the initial disparity. Addition of the parental resource variables further reduces the disparity by $44 \%$, to .500 (column 2 of table 3 ). With regard to the gap in early home ownership, we therefore conclude that differences between the ethnic groups in parental financial resources are by far the more important factor, accounting for some $86 \%$ of the reduction from the initial ethnic disparity.

In table 5 we report the ethnic gaps for the various living standard measures, before and after introduction of controls for the human capital/ employment/parental SES terms and the parental resource variables; the gaps were calculated from the ethnic effects in tables 3 and 4 and from models analogous to that in column 1 of table 3 . With respect to car ownership, the larger percentage reduction in the ethnic gap is again effected by the parental resource variables, possibly because the outlay necessary to acquire a car, as well as a home, can be substantial, often exceeding the financial assets accumulated by a young couple.

Parental wealth appears to play less of a role in explaining the ethnic gap in schooling; however, the parental characteristics in column 2 of table 4 include proxies for home environment and, therefore, are not strictly comparable to the other equations. Possibly, parental resources are less consequential because tuition costs have not been high in Israel; possibly because the decision to continue schooling heavily reflects cultural orientation, which is partially captured by the ethnic terms. Yet, even in the case of schooling, some $34 \%$ of the reduction in gap size can be attributed to differences in parental assets among the groups.

Last, with regard to the subjective measure, there is little reduction in the initial ethnic gap, either from the human capital variables or from the parental resource terms. As suggested earlier, it is not clear how respondents interpreted this question or how the appraisals of perceived living standards relate to ethnicity. In this regard, note that, in contrast with the other living standard measures, it is the Israel origin group (the omitted ethnic term) that reports the lowest subjective assessment of its living standard, rather than one of the objectively more deprived groups, either Asian or African descendants.

To summarize, in all the equations with objective measures of living standard (table 3; cols. 1 and 2 of table 4), the largest ethnic gap is between Ashkenazim (Europeans) and Mizrachim (Middle Eastern origin Israelis): a well-documented cleavage in Israeli society. In the instances of material assets (home, auto), the gap in ownership rate is largely explained by ethnic disparities in parental resources and demands on the resourcesEuropean origin parents have larger asset holdings and fewer children computing for the resources. In the case of schooling, a similar advantage is found for Europeans, relative to Israelis from a Middle Eastern back-

PROOF 20 
Impact of Parental Wealth on Early Living Standards in Israel

TABLE 5

Ethnic Disparities in Living Standard, First Three Years of Marriage

\begin{tabular}{|c|c|c|c|c|}
\hline \multirow[b]{2}{*}{ ETHNIC GAP } & \multicolumn{4}{|c|}{ Standard of Living Measure } \\
\hline & $\begin{array}{c}\text { Home } \\
\text { Ownership } \\
(1)\end{array}$ & $\begin{array}{l}\text { Automobile } \\
\text { (2) }\end{array}$ & $\begin{array}{c}\text { Schooling } \\
\text { (3) }\end{array}$ & $\begin{array}{c}\text { Subjective } \\
\text { Standard } \\
\text { of Living } \\
\text { (4) }\end{array}$ \\
\hline Initial disparity* ........... & .953 & 1.110 & 1.242 & .480 \\
\hline $\begin{array}{l}\text { Addition of human capital/ } \\
\text { employment and paren- } \\
\text { tal } \mathrm{SES}^{\dagger} \ldots \ldots \ldots \ldots \ldots \ldots \ldots\end{array}$ & .890 & .717 & .817 & .398 \\
\hline $\begin{array}{l}\text { Addition of parental re- } \\
\text { source terms }{ }^{*} \ldots \ldots \ldots \ldots . .\end{array}$ & .500 & .385 & .597 & .333 \\
\hline
\end{tabular}

ground. Yet, while disparities in parental assets contribute to the schooling gap, the primary factors in this instance appear to be noneconomic and derive from home environment and childhood socialization.

\section{EARLY LIVING STANDARDS AS AN UNOBSERVED CONSTRUCT}

There is value in also considering a model in which the living-standard construct is represented as an unobserved variable with several indicators. This formulation would capture the possibility that parental assistance is allocated differently among young couples, reflecting the diversity of their needs and desires-a home in one instance, a car or schooling expenses in a different household. A formulation using a single living-standard construct would lessen the confounding of lifestyle choice with level of consumption, since the various expenditure categories would be considered simultaneously.

This formulation can be represented as a MIMIC model (multiple indicators, multiple causes) in which a couple's parental wealth, along with proxies for household income at time of marriage, are seen as influencing the living-standard construct. This unobserved variable, in turn, is identified by its loadings on several living standard indicators. The equations for the MIMIC model are (Joreskog and Sorbom 1989, p. 173),

$$
\mathbf{Y}=\lambda \eta+\varepsilon,
$$

PROOF 21 
American Journal of Sociology

$$
\eta=\gamma^{\prime} \mathbf{X}+\zeta,
$$

where $\mathbf{Y}$ is a vector of indicators of the latent variable $\eta, \lambda$ is a vector of factor loadings relating the indicators to the latent variable, $\mathbf{X}$ is a vector of the exogenous "causes" of $\eta$, and $\gamma$ is a coefficient vector. The $\varepsilon$ 's and $\zeta$ 's are assumed to be mutually uncorrelated. Because the indicators of the living-standard construct are categorical variables, estimation is by weighted least squares.

The results from this estimation are presented in table 6 . The unobserved construct is identified by three indicators: home ownership, car ownership, and subjective standard of living in the first three years of marriage. The fourth consumption indicator available to us, schooling after marriage, was not used as it requires a causal structure that is different from the other consumption variables (see col. 2 of table 4). To establish the scale of the latent variable, the loading of the home ownership indicator was set to one.

Turning to the column 2 equation, which has the same regressors as the prior models, we find a causal structure that reflects the main thrust of the single indicator equations: husband's human capital and the couple's employment status have a significant effect on living standards; but, net of these terms, the parental resource variables have an equivalent impact. An increase of one parental home, for example, raises the value of the standard of living construct by .134 units (in this arbitrary metric), somewhat larger than the effect from an additional employed spouse (.094).

Also noteworthy are the year of marriage dummies and the ethnic terms. There is clear evidence in column 2 of a higher living standard in the initial years of marriage as we move forward in time; this presumably reflects the secular trend in economic development in Israel. As for the ethnic terms, they permit an account of the extent to which the ethnic gap in the summary living-standard measure can be explained by the various sets of variables. In particular, the initial maximum disparity, between Western European and African origin Israelis, is equal to 192 (column 1 of table 6). Introduction of controls for the human capital/ employment experiences of the couple and for the parental SES terms (not shown) lowers the gap to .169-a reduction of $12 \%$ from the initial disparity. Addition of the parental resource terms reduces the disparity by a further $43 \%$, to .097 (column 2 of table 6). Analogous to our earlier assessment, we conclude that the differences in parental resources among the ethnic groups is by far the more important factor in early living standards, accounting for some $76 \%$ of the reduction in gap size.

A final note on the models in table 6. Structural equation modeling

PROOF 22 
Impact of Parental Wealth on Early Living Standards in Israel

TABLE 6

Determinants of the Standard of Living in First Three Years of Marriage, MIMIC MODEL

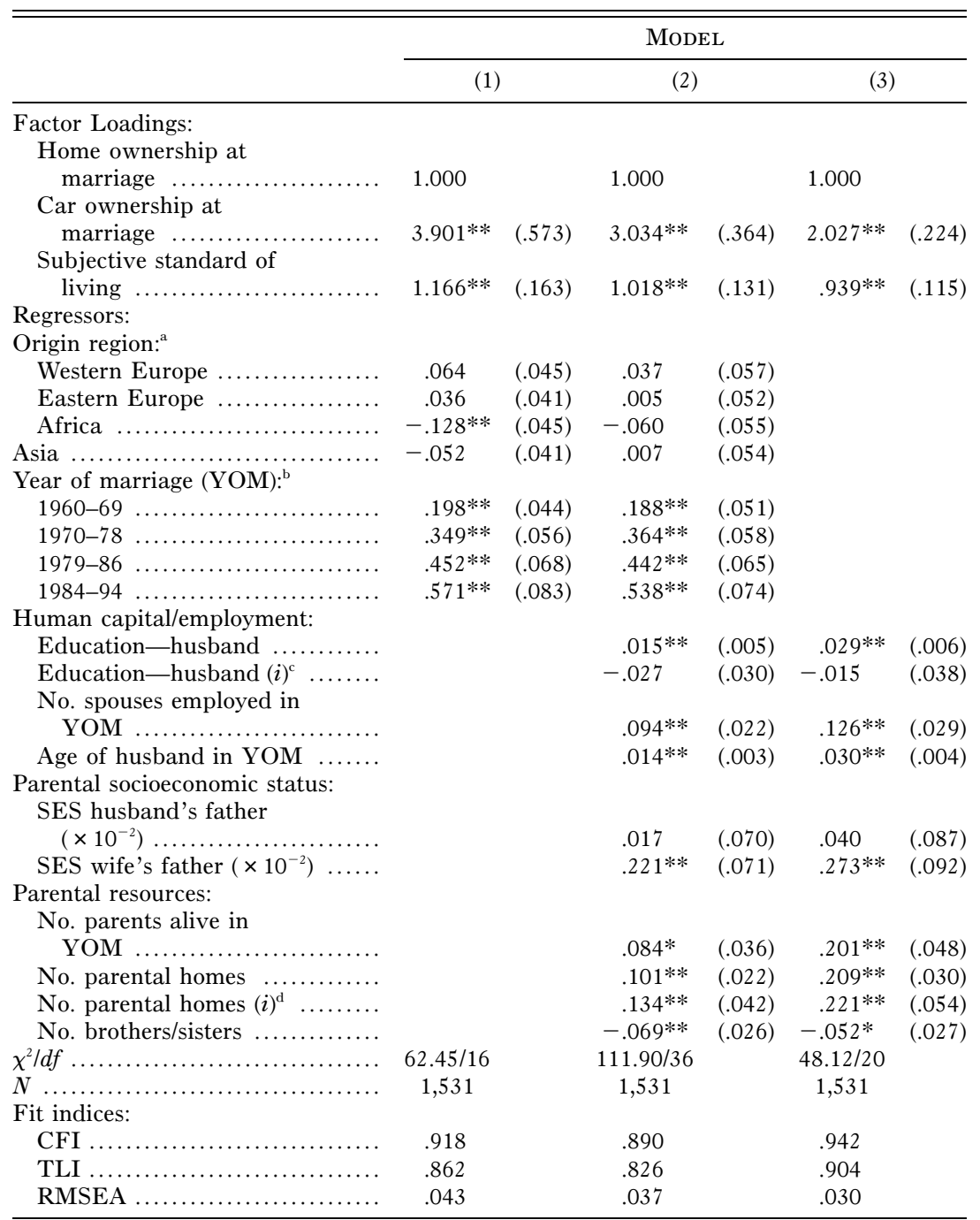

Note. - Estimates from multiple imputation, five data sets (see text for details). SEs in parentheses.

${ }^{a}$ Omitted term is for Israel origin.

${ }^{\mathrm{b}}$ Omitted term is for marriage before 1960 .

${ }^{\mathrm{c}}$ Indicator term for whether husband was a student during first three years of marriage.

${ }^{\mathrm{d}}$ Indicator term for missing data on parental homes. See text for details.

$* P<.05$, two-tailed test.

** $P<.01$.

PROOF 23 
American Journal of Sociology

(SEM) estimation minimizes the discrepancy between the covariance matrix of observed variables and the model implied covariance matrix. This approach permits tests of model fit, based on the discrepancy between the two matrices. According to the common fit indices, reported in table 6 , the first two equations do not adequately reproduce the observed covariance matrix. However, if the model is trimmed by dropping the ethnic and time period terms (equation 3) a satisfactory fit is obtained-the CFI and TLI indices each exceed 0.9 and the RMSEA value is below 05 .

For our purposes, however, the former models are more informative about the determination of living standards in Israel, in that they permit a discussion of the ethnic and time period effects. Note, also, that the qualitative findings implied by equation (3), the statistically preferred model, are identical to those drawn from equation (2). For these reasons we have focused on equations (1) and (2) in this account.

\section{CONCLUSIONS AND IMPLICATIONS FOR SOCIAL POLICY}

Parental resources and, presumably, transfers of resources-though the latter process was not examined directly-have had a massive impact on the living standards of young Israelis. They are critical factors in early home ownership and automobile acquisition, as well as in the likelihood of school attendance after marriage. This is the case even with controls present for parental SES and indicators of the earnings capacity and financial savings of the young couple. While our data are limited to a few aspects of living standards, because the measures that were examined tap different dimensions of this construct and because the findings are consistent across measures, we suggest that the consequence of parental asset holdings for living standards and life chances is quite pervasive.

At one level these results are not surprising. We expect children from wealthier homes to have access to greater financial resources and to live more comfortably than offspring from poor families. Indeed, parental background effects on educational attainment and early socioeconomic achievement were documented as far back as Blau and Duncan (1967, chap. 5). What this study adds to the established formulation is a consideration of the role of parental wealth. The value of this extension is that it permits an examination of the effects of direct transfers of financial and material resources across generations. In the Israeli case these effects are considerable.

The essential point is that, in Israel, parental wealth makes a huge difference for acquiring the basic ingredients of a modest living standard: a residence, a car, schooling. This is to be contrasted with the possible contribution of parental wealth to the acquisition of luxury items: a pres-

PROOF 24 
Impact of Parental Wealth on Early Living Standards in Israel

tige auto, a vacation home, the opportunity to drink fine wine. In short, the issue is not whether parental wealth confers an advantage, but at what point in the continuum of living standards it becomes a critical resource. In Israel, a recognition of the necessity of parental aid for maintaining even a modest lifestyle is apparent in the expressions reported in table 1 .

A comparison of the Israeli context with the opportunities of young adults in the United States to establish a "middle class" living standard can be illuminating. In the United States a well-educated young couple, even a couple from poor origin families, can expect to live comfortably on its labor market earnings upon school completion. It is possible to rent an attractive apartment and purchase an auto solely from earnings, especially if both spouses are employed. Indeed, in the United States, to a considerable extent, the decision to rent or purchase housing is a lifestyle choice. However, as noted, this is not the case in Israel because of the absence of a rental market. Young Israeli couples are compelled to purchase, and the role of parental resources in facilitating the acquisition is considerable. In our data, the home ownership rate in the initial three years of marriage closely tracks our proxy for parental wealth-the rate is $42 \%, 57 \%$, and $69 \%$ for couples with zero, one, and two parental homes (table 2).

In Israel, moreover, early home ownership is not just a living standard consideration. Because of restrictions on currency transfers and investment in foreign assets (which have been relaxed only recently), and because of the absence of a local stock market during much of the country's history, the principal vehicle of wealth accumulation has been residence purchases. Since housing values have climbed more steeply than the inflation rate, the acquisition of a home shortly after marriage has meant a greater number of years in which a couple might grow its resource base. As a consequence, the possibility of early home ownership, facilitated by parental assistance, has operated to magnify the existing disparity between the resources of the poor and the more affluent, as family assets are transmitted from one generation to the next.

This replication of advantage across generations has served to reinforce deep-rooted ethnic cleavages in Israeli society. In our data, Israelis of North African heritage own homes that have an average value of $\$ 133,000$ (1995 values, U.S. dollars) versus $\$ 181,000$ for European origin Israelis. ${ }^{18}$

\footnotetext{
${ }^{18}$ Home value data were collected in terms of five dollar categories: U.S. dollars are the currency of apartment sales in Israel. In computing home value figures, the bracketed categories were assigned their mean values; the low end category (less than $\$ 75,000$ ) was assigned the value $\$ 50,000$ and the high end, open category (greater than $\$ 300,000$ ) was assigned the value $\$ 400,000$. The sensitivity of results to alternate assignments of the open-ended categories was examined and found to be minimal, pre-
}

PROOF 25 


\section{American Journal of Sociology}

Also, the average number of children in families with completed childbearing is 4.2 for the former group, 2.7 for the latter. ${ }^{19}$ Thus, Israelis from European backgrounds are at a considerable advantage in regard to the parental resources potentially available for transfer to a child. Nor is it evident, especially in the absence of estate taxation, ${ }^{20}$ that this advantage can be eroded by the sorts of policies commonly instituted to uplift poor families: investments in schooling and human capital in the hope of narrowing the earnings gap. Because of the critical role of household wealth and the difficulty of asset accumulation from earnings in Israel, it is not clear that the ethnic disparity in living standards can be much reduced by a focus on educational attainment and skills deficits. The gap in household wealth, it must be remembered, captures the cumulative impact of past inequalities in household income and transfers, and it is resilient to rapid change via policies that seek to modify the incremental contributions to wealth by way of savings from earned income.

What implications can be drawn for the United States from this analysis? One cannot facilely assume that the institutional arrangements that have heightened the importance of parental wealth for young couples in Israel have a counterpart in the United States. Indeed, we have stressed the particular role of the housing market and liquidity constraints, for which there is little analogy in this country. ${ }^{21}$ At the same time, there are developments of a different sort in the United States that may inflate the role of parental wealth. Since the early 1970s, the average family income of household heads under age 25 has declined by some 23\% (Mishel, Bernstein, and Schmitt 1999, p. 45). This erosion is probably responsible for the failure of the home ownership rate of young adults in the United States to keep pace with the overall ownership rate (Wolff 2001, p. 57). Unlike in Israel, there is an alternative of rental housing: however, the decline in the ownership rate by this age cohort, relative to older households, can be interpreted as an indicator of growing economic distress among young families.

At the same time, since the 1970s there has been an increase in both the income and net worth of U.S. citizens in the age group 55-64-

\footnotetext{
sumably because some $91 \%$ of respondents reported housing values that fell into a closed bracketed category.

${ }^{19}$ Computations from the survey, based on women 45 and older.

${ }^{20}$ The issue of estate taxation, as part of a reform of the income tax system, has been on the agenda of recent Israeli governments, though no revision has yet been adopted.

${ }^{21}$ Yet, even in the United States, with low interest, long-term mortgages readily available, there is some evidence of parental wealth effects on early home ownership. For example, Mayer and Engelhardt (1996, p. 67) report that among first-time home buyers transfer recipients were six months younger and purchased a home worth $\$ 60,000$ more than nonrecipients', though both groups had virtually identical incomes.
}

PROOF 26 
Impact of Parental Wealth on Early Living Standards in Israel

presumably the parents of the aforementioned, younger cohort (Mishel et al. 1999, p. 45; Wolff 2001, p. 57). Thus, although little attention has been given to the possibility of a growing financial dependency of young families on the assets of their parents, the preceding developments raise this prospect. They point to a strengthening of the linkage between parental resources and the living standards of young families; in short, to a tightening in the replication of inequality across generations.

There also are broader trends that are likely to heighten the importance of household wealth in the United States-in regard to its service as a store of potential consumption as well as a factor in the transmission of inequality. In particular, the weakening of the social safety net, which has been in progress for some years, will necessarily mean that much of the risk from economic dislocation will be shifted from the public realm to the household unit. Families can reduce their vulnerability by increasing savings, which could be used to smooth consumption in a context of income fluctuation, or they can share risk with others: commonly parents and relatives. Young couples, however, tend to have little in the way of savings at this life stage; hence the contraction in public welfare programs is likely to further increase their reliance on the resources of parents.

The present analysis carries implications, as well, for the modeling of stratification processes. A consideration of intergenerational effects has long been a central theme in stratification research. However, the intergenerational transmissions have commonly been framed in terms of parental education and occupational status as the sole parental resources requiring consideration. Such a formulation makes sense as long as the measures of interest are the schooling and labor force attainments of offspring-outcomes heavily influenced by parental investments when the child is young and resides in the parental household. However, if attention is shifted to issues of the economic well-being and living standards of adult children, we would do well to incorporate measures of parental wealth into the formulation of parental resources.

This is desirable for two reasons. First, parental assets do eventually get transferred and make a contribution to living standards, along with a child's own earnings. Second, parental transfers are often made strategically and allocated over much of the life course-to facilitate the attainment of specific goals (e.g., the purchase of a home, opening a small business) or to protect offspring at a time of financial crisis (e.g., illness, job loss). See Spilerman and Torche (in press) for evidence of such effects in Chile. As such, the incorporation of parental asset holdings into the stratification paradigm would illuminate the intricate financial linkages that take place between generations, along with the specific ways by which parents target transfers to enhance the economic security and living stan-

PROOF 27 


\section{American Journal of Sociology}

dards of children, beyond investments made early in the life course in their stock of human capital.

\section{APPENDIX}

TABLE A1

Descriptive Statistics FOR the Explanatory Variables

\begin{tabular}{|c|c|c|c|}
\hline Variable & Mean & $\mathrm{SD}$ & $\%$ Missing \\
\hline \multicolumn{4}{|l|}{ Standard of living measures: } \\
\hline Home ownership .......... & .601 & .490 & 2 \\
\hline Auto ownership $\ldots \ldots \ldots \ldots$. & .401 & .490 & 1 \\
\hline Number in school ............... & .452 & .681 & 1 \\
\hline Subjective standard of living $\ldots \ldots \ldots \ldots \ldots \ldots$ & 2.834 & .761 & 1 \\
\hline \multicolumn{4}{|l|}{ Origin region: } \\
\hline Israel $\ldots \ldots \ldots \ldots$. & .060 & .238 & 1 \\
\hline Western Europe $\ldots \ldots \ldots \ldots \ldots \ldots \ldots \ldots \ldots \ldots \ldots \ldots \ldots$ & .121 & .327 & 1 \\
\hline Eastern Europe $\ldots \ldots \ldots \ldots \ldots \ldots \ldots \ldots \ldots \ldots$ & .332 & .471 & 1 \\
\hline 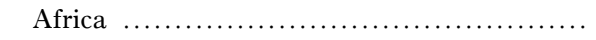 & .239 & .426 & 1 \\
\hline Asia $\ldots \ldots \ldots \ldots \ldots \ldots$ & .247 & .431 & 1 \\
\hline \multicolumn{4}{|l|}{ Year of marriage (YOM): } \\
\hline Before $1960 \quad \ldots \ldots \ldots \ldots \ldots \ldots$ & .125 & .331 & 0 \\
\hline 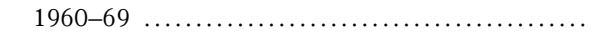 & .216 & .411 & 0 \\
\hline $1970-78$ & .272 & .445 & 0 \\
\hline 1979-86 & .215 & .411 & 0 \\
\hline 1984-94 „............................... & .171 & .376 & 0 \\
\hline \multicolumn{4}{|l|}{ Human capital/employment: } \\
\hline Education-husband ...... & 12.313 & 3.456 & 1 \\
\hline Education—husband $(i)^{*} \ldots \ldots \ldots$ & .236 & .425 & 1 \\
\hline No. spouses employed in YOM & 1.483 & .588 & 1 \\
\hline Age of husband in YOM & 25.470 & 4.226 & 2 \\
\hline \multicolumn{4}{|l|}{ Parental characteristics: ${ }^{\dagger} \ldots$} \\
\hline SES—husband's father ... & 42.612 & 18.522 & 8 \\
\hline SES-wife's father $\ldots \ldots \ldots \ldots \ldots \ldots \ldots \ldots \ldots$ & 42.540 & 18.332 & 8 \\
\hline Education—husband's father $\ldots \ldots \ldots \ldots \ldots$ & 8.140 & 5.307 & 30 \\
\hline Education-wife's father $\ldots \ldots \ldots \ldots \ldots \ldots \ldots$ & 8.570 & 5.051 & 24 \\
\hline \multicolumn{4}{|l|}{ Parental resources: } \\
\hline No. parents alive in YOM ...................... & 1.897 & .327 & 1 \\
\hline No. parental homes $\ldots \ldots \ldots \ldots \ldots \ldots \ldots \ldots$ & 1.380 & .744 & 19 \\
\hline No. parental homes $(\cdot i)^{\ddagger} \ldots \ldots \ldots \ldots \ldots \ldots \ldots$ & .194 & .395 & 0 \\
\hline No. brothers/sisters $\ldots \ldots \ldots \ldots \ldots \ldots \ldots \ldots \ldots \ldots \ldots$ & 6.820 & 4.440 & 1 \\
\hline
\end{tabular}

NOTE $-N=1,531$

* Indicator term for whether husband was a student during first three years of marriage.

† Imputed means for the education of husband's and wife's fathers are, respectively, 7.74 and 8.18 , somewhat lower than the observed means. However, these values are consistent with other information about the parents; e.g., husbands' fathers have an average SES of 38.8 in cases where educational attainment is missing, versus 44.3 where data on father's education is present.

${ }^{\ddagger}$ Indicator term for missing data.

PROOF 28 
Impact of Parental Wealth on Early Living Standards in Israel

\section{REFERENCES}

Allison, Paul. 2002. Missing Data. Thousand Oaks, Calif.: Sage.

Baltzell, E. Digby. 1958. Philadelphia Gentleman: The Making of a National Upper Class. New York: Free Press.

Becker, Gary S. 1975. Human Capital. 2d ed. New York: Columbia University Press. . 1981. A Treatise on the Family. Cambridge, Mass.: Harvard University Press.

Blau, Peter, and Otis D. Duncan. 1967. The American Occupational Structure. New York: Wiley.

Central Bureau of Statistics. 1967. Saving Survey 1963/64. No. 217. Jerusalem: Central Bureau of Statistics.

. 1994a. Family Expenditure Survey 1992/93: Part B-"General Summary.” No. 975. Jerusalem: Central Bureau of Statistics.

. 1994b. Survey of Housing Conditions, 1991. No. 956. Jerusalem: Central Bureau of Statistics.

Chartrand, Sabra. 1990. "Getting By in Israel, or, How to Stretch a Shekel." New York Times, August 8, p. A4.

Cohen, Yinon, and Yitchak Haberfeld. 1998. "Second Generation Jewish Immigrants in Israel: Have the Ethnic Gaps in Schooling and Earnings Declined?" Ethnic and Racial Studies 21:507-28.

Conley, Dalton. 1999. Being Black, Living in the Red: Race, Wealth, and Social Policy in America. Berkeley and Los Angeles: University of California Press.

Cox, Donald, and Mark Rank. 1992. "Intervivos Transfers and Intergenerational Exchange." Review of Economics and Statistics 74:305-14.

Davis, Kingsley, and Wilbert E. Moore. 1945. "Some Principles of Stratification." American Sociological Review 10:242-49.

de la Roca, Juan. 2000. "How to Obtain a Large Mortgage in Israel." Jerusalem Post, April 7, p. 19.

Duncan, Otis D., David Featherman, and Beverly Duncan. 1972. Socioeconomic Background and Achievement. New York: Seminar Press.

Elmelech, Yuval. 1992. "Immigrants, Young Couples and Housing Policy in Israel, 1948-1992.” Manuscript. Department of Sociology, Tel Aviv University.

Engelhardt, Gary, and Christopher Mayer. 1994. "Gifts for Home Purchase and Housing Market Behavior.” New England Economic Review, May-June, pp. 47-58.

Featherman, David, and Gillian Stevens. 1982. "A Revised Socioeconomic Index of Occupational Status: Application in Analysis of Sex Differences in Attainment." Pp. 141-81 in Social Structure and Behavior, edited by Robert M. Hauser, Archibald Haller, David Mechanic, and Taissa Hauser. New York: Academic Press.

Hamnett, C., M. Harmer, and Peter Williams. 1991. Safe as Houses: Housing Inheritance in Britain. London: Paul Chapman.

Heller, Mark A. 2002. "Money for Peace." Jerusalem Post. March 8, p. 8A.

Henretta, J., and R. Campbell. 1978. "Net Worth as an Aspect of Status." American Journal of Sociology 83:1204-23.

. 1980. "Status Claims and Status Attainment: The Determinants of Financial Well Being." American Journal of Sociology 86:618-29.

Holtz-Eakin, Douglas, and Timothy Smeeding. 1994. "Income, Wealth, and Intergenerational Economic Relations of the Aged.” Pp. 102-43 in Demography of Aging, edited by L. G. Martin and S. H. Preston. Washington, D.C.: National Academy Press.

Jencks, Christopher, Marshall Smith, Henry Acland, Mary Jo Bane, David Cohen, Herbert Gintis, Barbara Heyns, and Stephen Michelson. 1972. Inequality: A Reassessment of the Effect of Family and Schooling in America. New York: Basic Books.

PROOF 29 
American Journal of Sociology

Joreskog, Karl G., and Dag Sorbom. 1989. Lisrel 7 User's Reference Guide. Chicago: Scientific Software International.

Keister, Lisa. 2000. Wealth in America: Trends in Wealth Inequality. New York: Cambridge University Press.

King, Gary, James Honaker, Anne Joseph, and Kenneth Scheve. 2001. "Analysing Incomplete Political Science Data: An Alternative Algorithm for Multiple Imputation.” American Political Science Review 95 (1): 49-69.

Kohli, Martin. 1999. "Private and Public Transfers between Generations: Linking the Family and the State." European Sociological Review 1:81-104.

Kotlikoff, Laurence J., and Lawrence Summers. 1981. "The Role of Intergenerational Transfers in Aggregate Capital Accumulation." Journal of Political Economy 89: $706-32$.

- 1988. "The Contribution of Intergenerational Transfers to Total Wealth: A Reply." Pp. 53-67 in Modelling the Accumulation and Distribution of Wealth, edited by D. Kessler and A. Masson. Oxford: Clarendon Press.

Kraus, Vered. 1976. Social Grading of Occupations. Ph.D. dissertation (in Hebrew), Hebrew University, Jerusalem.

Kraus, Vered, and Robert W. Hodge. 1990. Promises in the Promised Land: Mobility and Inequality in Israel. Westport: Greenwood Press.

Lenski, Gerhard. 1984. "Income Stratification in the United States: Toward a Revised Model of the System." Research in Social Stratification and Mobility 3:175-205.

Matras, Judah. 1980. "Intergenerational Social Mobility and Ethnic Organization in the Jewish Population of Israel." Pp. 1-24 in Studies in Israeli Ethnicity: After the Ingathering, edited by A. Weingrad. New York: Gordon \& Breach.

Mayer, Christopher J., and Gary V. Engelhardt. 1996. "Gifts, Down Payments, and Housing Affordability." Journal of Housing Research 7 (1): 59-77.

McGarry, Kathleen, and Robert F. Schoeni. 1997. "Transfer Behavior within the Family: Results from the Asset and Health Dynamics Study.” Journal of Gerontology 52B:82-92.

Mills, C. Wright. 1956. The Power Elite. New York: Oxford University Press.

Mishel, Lawrence, Jared Bernstein, and John Schmitt. 1999. The State of Working America, 1998-99. Ithaca, N.Y.: Cornell University Press.

Modigliani, Franco. 1988. "Measuring the Contribution of Intergenerational Transfers to Total Wealth." Pp. 21-52 in Modelling the Accumulation and Distribution of Wealth, edited by D. Kessler and A. Masson. Oxford: Clarendon Press.

Mulder, C. H., and J. Smits. 1999. "First-Time Home-Ownership of Couples: The Effect of Intergenerational Transmission." European Sociological Review 15:323-37.

Oliver, Melvin, and Thomas Shapiro. 1995. Black Wealth/White Wealth. New York: Routledge.

Ornstein, Michael. 1976. Entry into the American Labor Force. New York: Academic Press.

Plessner, Yakir. 1994. The Political Economy of Israel. Albany: State University of New York Press.

Projector, Dorothy. 1964. "Survey of Financial Characteristics of Consumers." Pp. 285-93 in Federal Reserve Bulletin No. 50 (March). Washington: Board of Governers of the Federal Reserve System.

Rumberger, R. 1983. "The Influence of Family Background on Education, Earnings and Wealth." Social Forces 61:755-73.

Schafer, Joseph, and Maren Olsen. 1998. "Multiple Imputation for Multivariate Missing Data Problems: A Data Analyst's Perspective." Multivariate Behavioral Research 33 (4): $545-71$.

Semyonov, Moshe, and Noah Lewin-Epstein. 2001. "The Impact of Parental Transfers on Living Standards of Married Children." Social Indicators Research 54:115-37.

PROOF 30 
Impact of Parental Wealth on Early Living Standards in Israel

Semyonov, M., N. Lewin-Epstein, and S. Spilerman. 1996. "The Material Possessions of Israeli Ethnic Groups.” European Sociological Review 12(3):289-301.

Sen, Amartya. 1992. Inequality Reexamined. Cambridge, Mass.: Harvard University Press.

Shavit, Yossi. 1984. "Tracking and Ethnicity in Israeli Secondary Education." American Sociological Review 49:210-20.

Sherraden, Michael. 1991. Assets and the Poor: A New American Welfare Policy. Armonk, N.Y.: Sharpe.

Slemrod, J. 1991. "Taxation and Inequality: A Time Exposure Perspective." Presented at the NBER Conference on Tax Policy and the Economy, November.

Smooha, Sammy, and Vered Kraus. 1985. "Ethnicity as a Factor in Status Attainment in Israel." Research in social Stratification and Mobility 4:151-75.

Spilerman, Seymour. 2000. "Wealth and Stratification Processes." Annual Review of Sociology. Palo Alto: Annual Reviews.

Spilerman, Seymour, and Yuval Elmelech. 2003. "Israeli Attitudes about Inter-Vivos Transfers.” Pp. 175-95 in Global Aging and Challenges to Families, edited by Ver Bengtson and Ariela Lowenstein. New York: Aldine

Spilerman, Seymour, and Florencia Torche. In Press. "Living Standard Potential and The Transmission of Advantage in Chile." In What Has Happened to the Quality of Life in Advanced Industrialized Nations?, edited by Edward $\mathrm{N}$. Wolff. Cheltenham: Edward Elgar.

U.S. Bureau of the Census. 1964. Statistical Abstract of the United States, 1964, vol. 85. Washington, D.C.: Government Printing Office.

U.S. House of Representatives. 1992. Committee on Ways and Means: 1992 Green Book. Washington, D.C.: Government Printing Office.

Wilhelm, Mark. 1996. "Bequest Behavior and the Effect of Heir's Earnings: Test of the Altruistic Model of Bequests." American Economic Review 86:874-92.

Wolff, Edward N. 1996. Top Heavy. New York: New Press.

. 2001. "Recent Trends in Wealth Ownership, from 1983 to 1998." Pp. 34-73 in Assets for the Poor: The Benefits of Spreading Asset Ownership, edited by Thomas M. Shapiro and Edward N. Wolff. New York: Russell Sage Foundation.

Yideot Achronot. 1991. "Income 2,800 NIS, Expenditures 4,200 NIS" (in Hebrew). Yideot Achronot, December 17, p. 17. 


\section{American Journal of Sociology \\ QUERIES TO THE AUTHOR}

$1 \mathrm{I}$ believe I edited the abstract previously, but if so it disappeared along the way. I have restored it to the text here with the following changes: since AJS abstracts are limited to 100 to 125 words, I have cut the last sentence of the abstract. "State of Israel" in first sentence becomes simply "Israel."

2 See footnote 6 to determine if the mention of Federal News Service (formerly cited in References, but moved, with your OK, because it is a web address) has been correctly done.

3 See the last date ("1984 to 1994") of YOM in tables 3, 4, and 6. Should this be "1987 to 1994" (I use "to" rather than a hyphen, which can't be expressed in these queries.) 
American Journal of Sociology

Judd Hall 13-14

5835 South Kimbark Avenue

Chicago, IL 60637
Reprint Order Form

Please return this form even

if no reprints are ordered.

\section{( ) NO REPRINTS DESIRED}

I would like 5 free copies of the journal issue in which my article appears. ( ) YES $\quad($ ) NO

AUTHORS: REPRINT ORDER MUST BE RECEIVED PRIOR TO PRINTING OF JOURNAL ISSUE. Please return this form immediately even if no reprints are desired. Reprints ordered through an institution will not be processed without a purchase order number. Payment by check, Money Order, Visa, or MasterCard is required with all orders not accompanied by an institutional purchase order or purchase order number. Make checks and purchase orders payable to The University of Chicago Press.

TO BE COMPLETED BY AUTHOR:

American Journal of Sociology

Vol

No Month

Author(s): No of pages in article

Title of Article:

REPRINT PRICE LIST: Prices include shipping for U.S. and Canadian orders. Non-U.S and non-Canadian orders are shipped via Airmail at an additional cost of $45 \%$ of the total printing charge.

\begin{tabular}{|c|c|c|c|c|c|}
\hline \multirow[b]{2}{*}{ Pages } & \multicolumn{4}{|c|}{ Total Quantity } & \multirow{2}{*}{$\begin{array}{r}\text { add'l } \\
50 \text { 's }\end{array}$} \\
\hline & 50 & 100 & 150 & 200 & \\
\hline $2-4$ & $\$ 64.00$ & $\$ 76.00$ & $\$ 89.00$ & $\$ 100.00$ & $\$ 11.00$ \\
\hline $5-8$ & 71.00 & 91.00 & 110.00 & 126.00 & 19.00 \\
\hline $9-12$ & 77.00 & 111.00 & 139.00 & 165.00 & 28.00 \\
\hline $13-16$ & 86.00 & 123.00 & 156.00 & 188.00 & 34.00 \\
\hline $17-20$ & 98.00 & 146.00 & 190.00 & 234.00 & 44.00 \\
\hline $21-24$ & 105.00 & 161.00 & 214.00 & 265.00 & 53.00 \\
\hline add'। 4 pgs & 12.00 & 24.00 & 42.00 & 60.00 & 16.00 \\
\hline Covers & 93.00 & 105.00 & 123.00 & 140.00 & 19.00 \\
\hline
\end{tabular}

Shipping Instructions

Name

Phone* Fax

Dept Room Charges (please compute)

Covers Quantity

Subtotal

GST (7\% for Canadian destinations only)

Non-U.S./non-Canada orders add $45 \%$ to subtotal \$

$\$$

$\$$

$\$$

$\$$

44.00

$\$$

TOTAL DUE (US \$)

$\$$

Billing Instructions (Institutional Orders Only)

Institution

Street

City ___ State ___ Zip

Country

Institution

Phone

Street

email

${ }^{*}$ Please include a phone number in case we need to contact you about your order.

Country State Zip

MAKE CHECKS AND PURCHASE ORDERS PAYABLE TO: The University of Chicago Press

All orders must be accompanied by one of the three payment options (purchase order, check/money order, or Visa/MasterCard):

1) Institutional Purchase Order No. Purchase Order attached ( ) to come ( )

2) ( ) Check or Money Order for order will not be processed without a number 3) Please charge to: ( ) VISA ( ) MASTERCARD

Cardmember name as it appears on card (please print clearly)

Card Number Expiration Date

Signature

Phone 


\section{RETURN THIS REPRINT ORDER FORM WITH YOUR PROOFS (Airmail if non-U.S.) TO:}

AMERICAN JOURNAL OF SOCIOLOGY

Judd Hall 13-14

5835 South Kimbark Avenue

Chicago, IL 60637

\section{REPRINT INSTRUCTIONS:}

DO NOT DELAY ORDERING YOUR REPRINTS Orders must be in hand before the issue goes to press.

DELIVERY AND INVOICES Reprints are shipped 2-4 weeks after publication of the Journal. Invoices are mailed at the time of shipment. For all orders charged to institutions, an official Purchase Order must be in hand before the reprint shipment can be released. Reprint orders payable by individuals must be accompanied by advance payment by check, Money Order, Visa, or MasterCard. In case of non-U.S. purchases, this payment must be made in the form of a check payable in U.S. currency via an American bank. Terms are net 30 days. 